\title{
Impact of displacement on the psychological well-being of refugee children
}

\author{
MARINA AJDUKOVIC \& DEAN AJDUKOVIC \\ Department of Social Work $\mathcal{E}$ Department of Psychology, University of Zagreb E Society for \\ Psychological Assistance, Zagreb Croatia
}

\begin{abstract}
Summary
The war-related stress had a negative impact on the psychological well-being of all children in Croatia, but displaced and refunet children were especially affected. Although refugee children showed impressive resilience, particular attention should be devoted II $^{\prime}$ children who had traumatic experiences immediately prior to displacement. These children either lived without their parents or wuth parents who had poor coping abilities while displaced; lived in families that had accumulated several stressful experiences; or wrm housed in large collective refugee centers. The children that had poorer coping capacities and lacked a supportive family environmun! displayed high levels of stress-related symptomatology throughout the entire refugee period, being at special risk for the development of further psychological difficulties. The findings reported in this study are the result of a five-year follow-up of the same group of refugee children. Data about children's coping abilities with displacement were obtained primarily from mothers and the children themselves.
\end{abstract}

\section{Introduction}

Any war as a sudden, unpredictable, dramatic event has a tremendous negative impact at the community, family and individual levels. Usually, children are affected the most. From the studies done during and after the Second World War (Boardman, 1994), Yom Kippur War (Milgram, 1976; 1982), to the experiences from more recent wars (Baker, 1991), it is evident that war experiences can hinder the psychosocial development of children, and their expectations regarding future life. In this paper the effect of war and displacement on children in Croatia will be discussed.

The Republic of Croatia (4.7 million inhabitants) is a country located in Central Europe. It is one of the legal successors of the former Yugoslavia, and was recognized as an independent state by the United Nations in January 1992. The Croatian designation for independence was obtained in 1991, followed by an armed attack from the Yugoslav army that led to the first full-scale war in Europe since 1945. In 1992, this war spread to the territory of neighboring Bosnia and Herzegovina. Six years after the war started the reintegration of national territory was completed.

During the six-year period, hundreds of thousands of children were exposed to direct war activities (air raids, shelling and bombing), and their consequences (traumatization, multiple losses, abrupt changes in family structure and patterns, living with highly distressed adults, prolonged displacement, and dissolving communities). From the beginning of the war, governmental agencies, international humanitarian organizations and local non- governmental organizations devoted particular it tention to the needs of children in the war situation This paper summarizes some of these experiences, and presents evidence of children's suffering during this period.

\section{Children's losses during the war in Croatia}

Both during the war, and the years that followed, children in Croatia faced numerous losses. They were exposed to multiple traumatic events, potentially impeding their emotional and psychological development. The following traumatizing experiences and losses were particularly distressing and widespread.

\section{Loss of physical capacity}

In the period between May 1992 to October 1996, approximately 1,200 children were wounded, and another 303 killed (Office for War Victims, 1996). In the majority of cases, the causes of death were explosion and shooting injuries during artillery and air force bombing, or exposure to land mines. Among the injured children, 220 were permanently disabled. Extensively torn tissue, deep flesh wounds, and multiple injuries of a severe nature were typical (Grguric \& Remeta, 1994; Sikic et al., 1994).

\section{Loss of loved ones}

Many children lost their family members, close relatives and friends. Almost 5,500 children lost one

Correspondence to: Professor Marina Ajdukovic, Department of Social Work, Faculty of Law, University of Zagreb, 10000 Zagreb, Nazorova 51, Croatia. Tel: (385) 14821 205; Fax: (385) 14821206. 
parent and 74 children were orphaned. In many cases the children were witness to violence and death of their own family members. $U p$ to this time, another 900 children still have fathers listed as missing because of the war.

\section{Exposure to direct artillery shelling}

Many children were exposed to artillery attacks over a long period. In some cities immediate danger lasted for several months, requiring many children had to spend several days in cellars. A study done by UNICEF showed that $27.5 \%$ of displaced children spent more than a month in a bomb shelter, and that many of them $(28.6 \%)$ stayed in a shelter without their parents or other family members (Kuterovac et al., 1994).

\section{Displacement}

The majority of victims of the war were displaced children. From August 1991, a significant proportion of the Croatian population had to flee. The peak of the forced exile was the spring of 1992, when 356,627 persons had to flee from their homes. Almost half of them were children. At the same lime, refugees from Bosnia and Herzegovina also started to enter Croatia. At the end of 1992, the country was providing food, shelter and other kinds of support for almost 700,000 people, which was $14 \%$ of its population. Even by October 1997, there were still 287,366 people that remained displaced und/or had refugee status (ODPR, 1997).

Displaced children were faced with a whole range of losses: their homes, familiar environment, routine of an educational setting, social network, and usual patterns of family life among others. Some of these losses are described below.

l.oss of home. Home plays an important role in identity formation and development of children. Not only were the displaced children driven from their homes with only very few personal belongings und the grievous psychological consequences of the rvent, but in addition most of them had no home of llicir own anymore, and no place to go back to. 1) uring this war approximately 143,000 homes were cither completely destroyed or severely damaged.

I.uss of parental support and protection. At the peak of displacement (February-March 1992), approximntely 17,6000 displaced children within and outwide the country had been separated from their purents and/or were living without parental supervimion and care (ODPR, 1992). Even several years fucr, some displaced children, and many adolescents, were still separated from their parents beinuse of their educational needs which could not be Inct in communities of origin in which the school ware destroyed.
Living with distressed adults. Adult members of displaced families are themselves exposed to multiple stressors and trying challenges. Studies suggest that during warfare displaced adults frequently display anxiety, depression, anger, aggression, alcohol abuse, distrust, somatization or 'escape to illness', and sleep disturbance (Moro \& Vidovic, 1992). Often, the adults lose their jobs and no longer have access to employment, resulting in a decline in their social status. They feel degraded and demoralized, having to become financially dependent, and helpless. These cumulative negative effects produce high levels of stress, among the adults with disturbing consequences upon children (Ajdukovic, 1996; Ajdukovic \& Ajdukovic, 1993).

Loss of traditional way of living. Many children, especially those from rural areas, go through the acculturalization process during which they lose contact with traditional values and ways of living in their communities. These losses leave a big emptiness in the lives of many children. At the same time, change in the traditional way of living has a two-fold negative impact on children-when they have to adapt to an urban environment, or when they return to their communities of origin. Our first experiences with children who got the chance to go back to their villages after three, four or even six years of displacement, were that they were now going through another very stressful and painful period of reintegration (Druzic et al., 1997; Lopizic, 1995).

Lack of educational structure. Although extensive efforts to organize schooling for all displaced children were undertaken, less than half of the children were enrolled immediately after their arrival in whatever educational setting was available, given the circumstances. The major reason for this low level of enrollment was that many parents did not want their children to start a new school as they hoped to go back home soon. A number of traumatized high school students refused to continue schooling immediately. Several families found accommodation in areas that were not entirely safe, and occasionally shelled, so that it was not safe to hold classes (Dzepina et al., 1992).

Over time, all of the displaced and refugee children were enrolled in school, but many of them started displaying numerous difficulties in adapting to the new educational environment as they longed for their old schools (Svob, 1993). Displaced and refugee children had poorer conditions for learning, including high levels of spatial density in their temporary homes. They also displayed more psychological difficulties and problems of adaptation to their new surroundings (Ivanek \& Jakopovic, 1995).

Poor physical environment. Approximately 20\% of displaced people were accommodated in collective 
centers and the rest were in individual or family placement. In many cases, two or even three families with children had to share one room. Many children did not have a bed of their own. In most collective centers there was no place for play activities or for learning. Most children, who came from rural areas and were accommodated in high-rise refugee centers in cities, not surprisingly found limited possibilities for playing and using their free time in this new setting (Svob, 1993). Those that were accommodated with host families also experienced a lack of space. They were faced with high social density, lack of privacy and often poor quality of housing. Alongside this, children of the host families were also affected by the long-term displacement (Ajdukovic et al., 1992).

Malnutrition. Both in the preflight and displacement phases, a lot of children did not have access to adequate nutrition. With the growth of the displaced and refugee population, the financial possibilities for providing adequate food decreased. In general, dietary provisions were tailored to the needs of the adults, while the needs of infants and small children could not be adequately met. Studies of the nutritional status of school-age children, showed a significant degree of malnutrition. A third of the children had clinical symptoms secondary to nutritional deficiency (Grguric \& Hirsl-Hecej, 1993). Another study showed that one of every two children who lived in displacement longer than six months were malnourished (Svob, 1993).

\section{Changes in the community}

The war had an impact on the whole communitydestruction, forced uprooting of hundreds of thousands of people, leading to increased unemployment and poverty. This led to the distress of the whole community, with significant changes at the community level.

Some of these changes were:

- Loss of community balance and distortion of typical community value.

- Increased prejudice and social rigidity toward other groups.

- Problems of integration into a new social environment, emphasized in refugee and resettled families.

- Changes in priorities of the social welfare, health and educational systems.

- Preventive measures in the areas of juvenile delinquency, child abuse, neglect, alcohol and drug abuse, either disappeared at the community level or were significantly reduced.

- High level of traumatization of professionals and paraprofessionals (Ajdukovic \& Zic, 1997).
Impact of war on the psychosocial wellbeing of children

As described, due to the war children were faced with numerous losses, leading to stress and traumatization. Several studies have shown that when a child is faced with multiple and cumulative warrelated stressors, especially in the absence of appropriate support from family and the community, problems with psychosocial functioning are to bc expected (Garbarino et al., 1991; McCallin \& Fozzard, 1990). These findings were corroborated in studies done in Croatia. Although based on different methodology, they clearly documented different sources of distress, psychological suffering and problems of psychosocial adaptation by children exposed to war.

The most extensive screening looking at the psychological impact of war upon children was done within the UNICEF project 'Psychological and educational assistance to war-affected children' (Spoljaric, 1993; Kuterovac et al., 1994). In this study, 4,304 elementary school children participated. They were divided into six groups, according to the level of indirect or direct exposure to war destruction. The results showed that out of 25 possible traumatic war-related events, each child had experienced an average of seven of 25 such events. The highest score was found among the displaced children. On an average they were exposed to 11 traumatic events. In addition to exile and separation from family members, other traumatic events included exposure to life-threatening situations (air raids, shelling, extended stay in bomb shelters), threats to family members, witnessing acts of killing or violence towards others, and direct personal threats.

The children's distress was measured by the Impact of Events Scale (Horowitz et al., 1979). The study specially focused on estimating the proportion of children whose development was at risk due to the high levels of experienced stress. It showed that among the high-risk children, $39 \%$ of them were refugees, $35 \%$ were displaced, and $16 \%$ of these children were from parts of the country where there were no crises. The high level of distress among this last group of children, originated from indirect exposure to the war. The results of this study clearly indicated that all children in Croatia were affected by the war, although the risk was related to the level of exposure to the destruction caused by war.

The extensive body of data regarding distress among displaced children was aggregated over the period 1991-1996, within the framework of the project 'Psychosocial support to refugee families in collective centers' implemented by the Society for Psychological Assistance (a non-governmental, nonprofit mental health organization in Croatia) (Ajdukovic, 1994; 1996; Ajdukovic \& Ajdukovic 1993).

The aim of this paper is to illustrate the impact of war-induced displacement on children's well-being. Three indicators of children's mental health status 
ure discussed: (1) mothers' assessment of children's ntress reactions; (2) the post traumatic stress reactions of children; and (3) the level of depression of children during displacement.

\section{Jiramework and methodology}

The data presented in this paper was gathered within the framework of a program that provided psychosocial assistance to families with children in a collective refugee center in Zagreb, Croatia. This refugee center accommodated 600 displaced people, mainly from the Hrvatska Kostajnica area. This was one of the earliest collective centers in the country, established in August 1991. Before the war these buildings served as dormitories for secondary school students. There were three four-floor buildings, with a bathroom on each floor and central heating. People were accommodated in large rooms, and different families often had to share a room. Overall, the space was overcrowded.

In 1991, a group of professionals, initiated the program of psychosocial assistance to traumatized children in this center. The program was developed over time, and in early 1992 its objectives were defined as follow: (1) to identify the sources of stress in exile, (2) to identify families with children manifesting difficulties in adjustment, (3) to develop a program for delivering psychosocial assistance to children and their families living in an unnatural environment of the collective refugee center, and (4) to monitor the effects of interventions.

A large majority of the refugees lived in this center for over five years, by and large up to the time that they could go back to their homes. Some of them were still there in October 1997. In 1996, when the majority of refugees repatriated to the Hrvatska Kostajnica area, the project changed its focus, to facilitating the process of social reconstruction and integration in the communities of origin. Displaced mothers and children were interviewed three times, over a period of three years.

\section{First psychosocial assessment (March 1992)}

The first assessment of families with children involved 65 mothers being approached. They provided information about 110 children up to the age of 18 , and 137 adult members of their families. This was the initial pool of participants that was followed-up. Most of the families (70.4\%) had three or more children; in just over half of the families $(53.8 \%)$ the father was absent, either at the front or assigned to obligatory labor duties close to the front line. At the time of the first interview, $98.5 \%$ of the participants had been displaced for five to six months. The interviews were designed to have a therapeutic effect in addition to establishing the first contact with the families, presenting the program and gathering baseline data. It became very clear that for the vast majority of these women, this was the first time since fleeing their homes that they had had a chance to talk to someone outside of their own refugee social circle. They talked about their feelings, fears, traumatizing experiences, losses, hopes and expectations and, of course, shared their concerns about their children. They saw this as an opportunity to seek information concerning their everyday problems (such as legal status and rights, health care provisions, or schooling and day care opportunities for their children). This was also a good opportunity for the team members to present themselves and inform the clients about the variety of program activities that were being planned.

Based on the assessment of needs a comprehensive assistance program was developed and implemented. It included individual and group activities for children, adolescents and the elderly, sports and recreational activities, as well as individual and family counseling when deemed appropriate.

\section{The second psychosocial assessment (August 1992)}

The second assessment was done six months later, during which time the same mothers were approached again. At that time, 58 mothers provided information about 102 of the same children. The objective of this assessment was to obtain insight into the process of adaptation to displacement, and to evaluate outcomes of program implementation.

\section{The third and last psychosocial assessment (Fuly 1995)}

The third assessment involved approaching the same original group of mothers. During this phase of the assessment, 51 mothers provided information about 50 of the original group of children. During the entire period (March 1992-July 1995), some mothers were approached several more times as part of the evaluation procedure of ongoing program activities. On such occasions, only mothers of children that had been actively involved in certain activities were approached. However, in this paper, data provided by all of the mothers who lived with their children through this entire period is presented.

The children themselves were approached for the first time in January 1993. At that time, 52 children between the ages of nine and 14 were interviewed. The second assessment included 48 of these original 52 children, done in July 1993. This group of children was followed-up almost till the end of displacement. The last assessment was done approximately three years later, in February 1996. Although the process of repatriation was already underway, at that time there were still 14 children, from the original group of 52, living in the same collective center. The other 38 had either become older than 14 years of age, or had returned to their original communities. 
The children were interviewed because of the realization that in some families the mothers themselves were overwhelmed by problems and did not have the capacity to recognize and assess their children's difficulties. Furthermore, the other two indicators of children's mental health status were self-report measures.

Although at each time interval all of the displaced mothers and all the children aged nine to 14 living in the collective center at any given point were interviewed, this paper includes results of only the original mothers and their children who lived there the entire time. As one can imagine, the life in a collective center is not a static one: some families were moving out, while others were moving in. Over a five-year period some children had grown up, so that they no longer met criteria for assessment as 'families with children'. Therefore, the number of participants in the sample decreased over time.

Although the same group of children was followed, this study was not envisioned as a classic longitudinal research study. The first assessment was done primarily to identify families with children that had the most severe problems of adjustment in displacement. At that time, almost everyone believed that the crises would be over in a few months and that the families would be able to return to their communities of origin. Therefore, further assessment points were chosen according to the needs for monitoring the general process of adjustment and evaluation of the outcomes of program activities. But, very often the plans had to be changed due to extraneous circumstances. For example, in 1995 it was planned to approach mothers and children in the same time period. However, just as the assessment procedure with mothers was completed and the children were to be interviewed, the major military operation 'Oluja' was launched and the optimism of displaced families dramatically increased. Many of them expected to return to their homes in several weeks. At the time of this euphoric state, the participants were not motivated to be interviewed about their adaptation difficulties such as depression or post traumatic reactions. However, the reality was that the process of resettlement proved to be a very slow one. A considerable number of children remained in the collective center for almost another year, at the time of the last assessment.

The same set of instruments were administered at each time interval, both for the mothers and the children. However, the Stress Events Scale (Ajdukovic et al., 1992) was used only during the first interview.

When the mothers were interviewed the following instruments were used each time:

(1) The mother's assessment of her relationship with her children during displacement.

(2) The mother's assessment of the symptoms of stress manifested by her children before and during displacement.
(3) The mother's assessment of her own streswrelated reactions, including among other me sures-depression and post traumatic stress $\mathrm{tc}^{\mathrm{t}}$ actions measured by the Post Traumatic Stres. Reactions Scale (adult version, PTSR-O: $\Lambda$; dukovic et al., 1992).

(4) The background characteristics of the family.

When the children were interviewed, the followins instruments were administered each time:

(a) Post Traumatic Stress Reaction Scale (child version, PTSR-D: Ajdukovic et al., 1993).

(b) Child Depression Inventory (CDI: Kovacm, 1981).

(c) Parental acceptance-rejection questionnairc (PARQ: Rohner, 1984).

(d) Social and demographic characteristics questionnaire.

The selection of instruments was based on the model for providing psychosocial assistance to refugees (Ajdukovic, 1993). Some of the instruments were specifically designed for this project.

\section{Results}

Stress reactions of displaced children: mothers' perciptions

Exposure to living in displacement is likely to result in a number of stress-related symptoms in children (McCallin \& Fozzard, 1990; Ressler et al., 1988). The mothers were asked to identify from a given list, stress-related symptoms that they observed in the" children since living in exile (Table 1). They werc also asked if their children had experienced any of those symptoms before the war (Table 2).

Displacement had a strong negative impact on the children's wellbeing, as indicated by their mothers' estimates. After six months of displacement (first assessment) there was a substantial increase in all ol the symptoms. The most common reactions of chil dren were the following: eating disorders (overly decreased or increased appetite in $31.8 \%$ of the children), sleep disturbances (16.4\%), nightmarcs (22.7) and increased sweating (6.4\%). Behavioral manifestations reported were: defiance (12.4\%), as gression and hyperactivity $(29.1 \%)$ and withdrawal $(9.1 \%)$. In the emotional domain the following wer. most prominent: separation fear $(25.5 \%)$, despon dency $(22.7 \%)$, general fearfulness $(19.1 \%)$ and weeping (16.4\%). Mothers also reported that $16.4 \%$ of the children started to have concentration difficulties.

As shown in Table 2, at the time of the first assessment $28.2 \%$ of the children did not exhibil any of the aforementioned stress symptoms, whilc $22.7 \%$ of the children exhibited five or more of the stress symptoms. After 12 months of displacement, during the second assessment, the number of stress symptoms manifested by the children decreased 
ea-

re-

ess

$\mathrm{Aj-}$

\begin{tabular}{|c|c|c|c|c|c|c|c|c|}
\hline \multirow[b]{3}{*}{ Silçs symptoms } & \multicolumn{4}{|c|}{$\begin{array}{l}\text { First assessment } \\
\qquad N=110\end{array}$} & \multirow{2}{*}{\multicolumn{2}{|c|}{$\begin{array}{c}\text { Second } \\
\text { assessment } \\
N=102\end{array}$}} & \multirow{2}{*}{\multicolumn{2}{|c|}{$\begin{array}{c}\text { Third } \\
\text { assessment } \\
N=50\end{array}$}} \\
\hline & \multicolumn{2}{|c|}{$\begin{array}{c}\text { Before } \\
\text { displacement }\end{array}$} & \multicolumn{2}{|c|}{$\begin{array}{c}\text { Since } \\
\text { displacement }\end{array}$} & & & & \\
\hline & $N$ & $\%$ & $N$ & $\%$ & $N$ & $\%$ & $N$ & $\%$ \\
\hline \multicolumn{9}{|l|}{ Physicnl manifestation } \\
\hline llurmg disorders & 3 & 2.7 & 35 & 31.8 & 21 & 20.6 & - & - \\
\hline Slceping disturbances & 2 & 1.8 & 18 & 16.4 & 10 & 9.8 & - & - \\
\hline Nimlumares & 3 & 2.7 & 25 & 22.7 & 10 & 9.8 & 2 & 4.0 \\
\hline Swcoting & 2 & 1.8 & 7 & 6.4 & 2 & 1.8 & 1 & 2.0 \\
\hline $\begin{array}{l}\text { Hculth problems } \\
\text { (brewling, heurt beating, allergy) }\end{array}$ & 1 & 0.9 & 15 & 13.6 & 9 & 6.9 & - & - \\
\hline Sprenking difficulties & 3 & 2.7 & 4 & 3.6 & - & - & 1 & 2.0 \\
\hline Tickn & 2 & 1.8 & 3 & 2.7 & 3 & 2.9 & 1 & 2.0 \\
\hline 1'murcwis und encopresis & 1 & 0.9 & 3 & 2.7 & 3 & 2.9 & 2 & 4.0 \\
\hline \multicolumn{9}{|l|}{ IH:haviors } \\
\hline Defiunce & 4 & 3.6 & 14 & 12.7 & 16 & 15.7 & 5 & 10.0 \\
\hline Aguremion and hyperactivity & 2 & 1.8 & 32 & 29.1 & 23 & 22.5 & 7 & 14.0 \\
\hline Withdruwal & 6 & 5.4 & 10 & 9.1 & 8 & 7.8 & 2 & 4.0 \\
\hline $\begin{array}{l}\text { Delerioruting contact with } \\
\text { fumily members }\end{array}$ & 1 & 0.9 & 5 & 4.5 & 6 & 5.5 & 1 & 2.0 \\
\hline Sell-inllicted injuries & - & - & 2 & 1.8 & - & - & 一 & 一 \\
\hline \multicolumn{9}{|l|}{ Jinotions } \\
\hline Sepuration fear & 4 & 3.6 & 28 & 25.5 & 22 & 21.6 & 5 & 10.0 \\
\hline Dewpondency & - & - & 25 & 22.7 & 8 & 7.8 & 1 & 2.0 \\
\hline (ieneral fearfulness & - & - & 21 & 19.1 & 7 & 6.9 & - & - \\
\hline 'leurfulness & 2 & 1.8 & 18 & 16.4 & 14 & 13.7 & 1 & 2.0 \\
\hline Anger toward family & 1 & 0.9 & 10 & 9.1 & 5 & 4.9 & 4 & 8.0 \\
\hline licur of objects and situations & 1 & 0.9 & 13 & 11.8 & 4 & 3.9 & 2 & 4.0 \\
\hline \multicolumn{9}{|l|}{ Memory and thinking } \\
\hline Cuncentration difficulties & 4 & 3.6 & 18 & 16.4 & 7 & 6.9 & 6 & 12.0 \\
\hline
\end{tabular}

umiderubly $(t=3.86, p<0.01)$. Nevertheless, acwring (1) the mothers' assessments, more than half uf the children still manifested at least one of the larlichlors of adjustment difficulties, and 10.8\% inunlfested five or more (Table 2). The most persistsill mircss-rclated reactions were aggressive behavfurk $(22.5 \%)$, eating disorders $(20.6 \%)$, separation fenr (21.6\%), defiance (15.7\%), tearfulness (13.75), Iinhlinares $(9.8 \%)$ and sleep disturbances $(9.8 \%)$ ('able 1). A significant correlation $(0.448, p<0.01)$ whw found between the number of stress symptoms the child manifested during the first and second amessments. This indicates that it is more damaging III' wome children to live in displacement.

'I 'he correlation analysis was carried out between lic overall number of stress reactions in a specific liuld and different aspects of family interaction. special attention was directed towards the adapiurion of the mother to displacement and the - hunges in her relationship with the child. The umunber of adjustment difficulties in children correlucd with the mother's post traumatic stress reacImns ( $r=0.350, p<0.01$ ). In addition, the study dcmonstrated that the number of stress reactions mianifested by children was related to the decrease "If gentleness of the mother $(r=0.358, p<0.01)$. Ihere was also a significant correlation between the number of children's symptoms and separation from other members of the family. These findings once again confirm the significance of a stable emotional relationship between parents and children for the child's ability to cope with unfavorable circumstances. They are in accordance with the research of McCallin and Fozzard (1990), who also reported a correlation between the intensity of psychosocial difficulties in the mother's adjustment to displacement and of stress-related reactions in the children of Mozambique.

The third assessment done three years after the second one showed that the majority of children's stress-related symptoms significantly decreased (Table 2) and that they came close to the prewar period (Table 1). Again, the number of stressrelated symptoms significantly correlated with the mother's post traumatic stress reaction score $(r=0.270, p<0.05)$. There was also a significant, but moderately high correlation among the number of stress symptoms the child manifested during the three times $r_{1,3}=0.492, r_{2,3}=0.390, p<0.01$ ). Therefore, children who manifested a higher number of difficulties after the first 6 months of displacement, also manifested them after 12 months, and even after 4 years. Perhaps, those were the children whose development was at risk, even before the displacement, and exposure to chronic refugee stress additionally aggravated their developmental process. 
Table 2. Number of stress reactions among the same group of displactd children at three time points as reported by thcir mothers

\begin{tabular}{|c|c|c|c|c|c|c|}
\hline & \multicolumn{2}{|c|}{ March 1992} & \multicolumn{2}{|c|}{ July 1992} & \multicolumn{2}{|c|}{ July 1995} \\
\hline & $N$ & $\%$ & $N$ & $\%$ & $N$ & $\%$ \\
\hline \multicolumn{7}{|c|}{ Number of symptoms } \\
\hline None & 31 & 28.2 & 38 & 37.3 & 32 & 64.0 \\
\hline One to two & 24 & 21.8 & 36 & 35.3 & 10 & 20.0 \\
\hline Three to four & 30 & 27.3 & 17 & 16.6 & 6 & 12.0 \\
\hline Five and more & 25 & 22.7 & 11 & 10.8 & 2 & 4.0 \\
\hline Mean & 2.86 & & 1.75 & & 0.92 & \\
\hline $\mathrm{SD}$ & 2.89 & & 1.99 & & 1.70 & \\
\hline Maximum & 14 & & 8 & & 8 & \\
\hline Total & 110 & & 102 & & 50 & \\
\hline
\end{tabular}

Stress reactions of displaced children: children's self report

As a measure of children's stress reactions in displacement, two parameters were followed over time-the post traumatic stress reactions and the level of depression:

(a) The post-traumatic stress reactions were measured by the PTSR-D scale, which included 24 items with a three-point scale. The possible range of scores was 24 to 72 . The scale was developed according to the DSM-III-R criteria for the purpose of this study. No comparable data for other groups except refugee children were available. The overall results showed that post traumatic reactions were moderately present (Table 3). Older children reported more post traumatic stress symptoms than the younger ones $(r=0.312, p<0.05)$.

(b) Children's depressive symptoms were measured by the Child Depression Inventory (CDI: Kovacs, 1981). The inventory contains 27 items that cover a broad range of depressive symptoms in children. For each item three short statements are presented and the child is asked to choose the one that best describes his or her feelings, thoughts and behaviors during the preceding two weeks. The inventory, according to Kovacs, is not intended to be used as a clinical diagnostic instrument, but rather as a screening measure for depression. Children with high scores on the CDI are characterized both by higher rates of depression and anxiety. The scale was first adapted for use in Croatia in 1990, just before the war (Zivcic, 1993).

It was found that the depression score for refugee children was significantly higher than the score for school children before the war. At the same time, there was no difference between the refugee children and a clinical sample of children who were treated before the war, in a mental health institution for psychosomatic problems, school failure, depression and anxiety. Moreover, $22 \%$ of refugee children, compared to $18 \%$ of children from the clinical sample, had a score of 18 or higher, a score generally considered to be clinically significant.

A comparison of refugee children, with a group of school children who had not been displaced during the war, revealed interesting findings. Although the displaced children had slightly higher scores on the CDI, there was no significant difference between the two groups, corroborating the findings of Zivcic (1993). However, both groups showed more depressive symptoms compared to children of the same age who were assessed before the war. Obviously, the war stressors had negative impact on the emotional functioning of all children. However, a study done two years later (Vrdoljak, 1994) did not find significant differences between displaced children and a comparable group of non-displaced children. But the overall level of depression was lower than in 1992 and close to the prewar time.

At six-months follow-up (January-July 1993), there was a significant decrease of depressive and post traumatic stress reactions among refugee children (Table 3). The correlation analyses revealed that the level of refugee children's depression was not related to the number of traumatic events, but rather to the family situation, child's age and the child's poor coping abilities during displacement, especially school difficulties. Deteriorating relations among family members, mother's poor relationship

Table 3. Depressive symptoms and post traumatic stress reactions in refugee children, $N=48$

\begin{tabular}{lcccc}
\hline $\begin{array}{l}\text { Time of } \\
\text { assessment }\end{array}$ & $\begin{array}{c}\text { January } \\
1993\end{array}$ & $\begin{array}{c}\text { July } \\
1993\end{array}$ & $t$-test & $r_{1,2}$ \\
\hline CDI & & & & \\
$M$ & 11.89 & 10.21 & $2.28^{\star}$ & $0.54^{\star \star}$ \\
SD \pm & 5.18 & 5.10 & & \\
PTSRS & & & & \\
$M$ & 35.00 & 32.83 & $2.05^{\star}$ & $0.47^{\star \star}$ \\
SD \pm & 6.21 & 7.73 & & \\
\hline
\end{tabular}

CDI: Children's Depression Inventory, PTSRS: Post Traumatic Stress Reaction Scalc. ${ }^{\star} p<0.05,{ }^{\star \star} p<0.01$. 
I ulu 4. Correlates of the Child Depression Inventory (CDI) score for displaced children (first assessment)

CDI

(r)

Annessed hy mother

Clukd's gencral stress index

Monluer's poor relationship with , hild

$0.38^{\star \star}$

Ammenurel by child

Aluher's general rejection index

I) cerviurating relationship among lanily members

t 'llild's poor coping in displacement

silooul problems

Ane

$0.31^{\star \star}$

$0.27^{\star}$

$-0.27$

$0.28^{\star}$

$0 p=0105, * n<0.01$.

m-
Iululv 5. Level of depression (CDI) and post traumatic stress W.1. Iin. (I'TSR) for a group of 14 refugee children over a period of thrie years (February 1993-May 1996)

\begin{tabular}{|c|c|c|c|c|c|}
\hline fline uf & $\begin{array}{c}\text { January } \\
1993\end{array}$ & $\begin{array}{c}\text { July } \\
1993\end{array}$ & $\begin{array}{l}\text { May } \\
1996\end{array}$ & $t_{1,2}$ & $t_{2,3}$ \\
\hline \multicolumn{6}{|l|}{ c11 } \\
\hline$M$ & 11.25 & 9.42 & 11.83 & 0.44 & 1.85 \\
\hline$v_{11}=$ & 6.90 & 5.94 & 6.28 & & \\
\hline \multicolumn{6}{|l|}{ FI'SIRS } \\
\hline$M$ & 33.50 & 34.07 & 34.21 & 0.419 & 0.06 \\
\hline sill. & 6.27 & 10.37 & 6.34 & & \\
\hline
\end{tabular}

D11/ Children's Depression Inventory, PTSRS: Post I lummatic Stress Reaction Scale.

wilh the child since becoming a refugee, and the Inlit's perception of rejection by the mother, were munificunt correlates of the child's depression (linble 4).

The tinal children's self-assessment was done in May 1096. At that time only 14 children from the unisiual sample were still living in the collective unt.r or belonged to the target age group. Their rmulis are presented in Table 5. For this group, unlu. of the two measures of mental health mutus - level of depressive symptoms, and post traumulic stress reactions - changed during the period of Hure ycars. In May 1996, their scores were even 4111.what higher than in July 1993. A case by case unilyses showed, that these children had poorer mmpects for resettling in their original communi$11 \%$, and had more unfavorable family situations.

\section{I iscussion}

I lice is no doubt that children in displacement uresent a group whose development is at risk. At hle same time displaced children also showed immessive resilience, and many strategies to cope with prolonged exposure to the chronic refugee stress. ( $u r$ findings reaffirmed the importance of the family and the support it provides to a child in coping with the prolonged stressful situation of displacement. The data also revealed that even in such situations where multiple stressors have a cumulative effect over time, the incidence of stress-related reactions in children decreases. Nevertheless, it must be kept in mind that the child's exposure to extremely intense stressors can have delayed effects, and can cause difficulties in psychosocial functioning in adulthood. A limitation to the generalization of these findings is the relatively small sample size studied over time. One might also question the validity of the information obtained from the mothers about their children, especially if they themselves had psychological difficulties and were not entirely sensitive to the difficulties of their children. However, gathering information from the children also had its own limitations. Younger children were not able to give reliable accounts of their feelings in displacement, while older children were sometimes unaware of all the aspects of their behavior and reactions, or were trying not to burden their parents with additional problems. This study could not answer the question about the causes of persistent adjustment difficulties in children after 12 months of displacement despite being together with at least one parent. But it was possible to determine the correlates of poor adaptation.

Although the assessments were used to plan and provide psychosocial support to children and families, it was very difficult to estimate the impact of these activities in the reduction of stress-related symptoms in children. This could only be possible if the classic experimental design included a control group. But such a research model would be ethically inappropriate in a war situation, when the whole community is distressed. As a part of the psychosocial support program to children and their families, the following activities were offered: social skills training for children of different ages, support to children with schooling problems, therapeutic theater for adolescents, family counseling, and structuring of leisure time activities. These activities were found to be helpful in improving the childrens' coping abilities while displaced. They were highly evaluated by both the children and their parents. Further evidence of the utility of these interventions became apparent only after the outreach program in the resettlement community was started. It became evident that the children who had benefited from the psychosocial support activities in displacement showed much fewer adjustment problems compared to children who had no access to this kind of assistance. Very soon many of 'our children' became peer facilitators in their new school setting. Attention is also drawn to the problems of repatriation that may cause further stress for some children. Therefore, carefully planned preparation and outreach programs for the repatriated refugees, children and their families, should be provided. Experience drawn from outreach assistance programs during refugee life can serve as a valuable starting point. 


\section{Conclusion}

The evidence of multiple sources of distress and traumatization indicate that psychosocial development of many children in Croatia was, and still is at risk. The results can be summarized as follows:

- War-related stress had a negative impact, on the psychological wellbeing of all children in Croatia from babies to adolescents, but displaced and refugee children were especially affected.

- Refugee children showed impressive resilience. Therefore, it is important to study further the causes of resilience in displacement.

- Particular attention should be devoted to children who had traumatic experiences immediately prior to displacement. Others at risk were those who lived without parents, or with parents whose coping abilities in displacement were very poor; or lived in families that had cumulative stressful experiences, or those who were housed in large collective refugee centers.

- Children who had poorer coping capacities and lacked a supportive family environment displayed high level of stress-related symptomatology throughout the entire refugee period, being at special risk for the development of further psychological difficulties.

These findings have been used to develop outreach assistance programs for displaced children and others growing up in war zones. Such programs are primarily aimed at the 'here and now' and directed towards providing primary and secondary mental health prevention.

\section{References}

Ajdukovic, D. (Ed.) (1993). Psiholoske dimenzije progonstva (Psychological dimension of displacement) Zagreb: Alinea.

AjDukovic, D. (1995). Post traumatic and depressive symptoms in refugees: correlates, predictors and changes. Paper presented at the Fourth European Conference on Traumatic Stress, Paris, 7-11 May.

Ajdukovic, D., Ajdukovic, M. \& Corkalo, D. (1992). Stress event scale. Zagreb: The Society for Psychological Assistance.

Ajdukovic D., Arambasic, L. \& Ljubotina, D. (1992). Post traumatic stress reactions scale. Zagreb: The Society for Psychological Assistance.

Ajpukovic, M. (1994). Traumatic stress in refugee children in Croatia. Paper presented at the 23rd International Congress of Applied Psychology, Madrid, July 17-22.

AjDukovic, M. (1996). Mothers' perception of their relationship with the children during displacement: a sixmonth follow-up. Child Abuse Review, 5(1) 34-49.

AjDukovic, M. \& Ajdukovic, D. (1993). Psychological well-being of refugee children. Child Abuse $\mathcal{E}$ Neglect, 17(6), 843-854.

Ajdukovic, M., Miljevic, R. \& Pecnik, N. (1992). The influence of displacement on the relationship of mothers to their children accommodated in host families. Psychologische Beitraege, 34(3/4), 199-205.
Al)uK(IVIs, M. \& ZIC, B. (1997). Prevention of delinquent experience in childhood: Croatian experience. Paper presented at the 7th European Conference on P'sychology and I aw, Stockholm, September 3-6.

BAKI:R, A. (1991). Psychological response of Palestinian children to environmental stress associated with military occupation. Foumal of Refugee Studies, 4, 237-247.

BOARDMAN, F. (1994). Child psychiatry in wartime Britain. Foumal of Education Psychology, 35, 293-301.

Dru'ic O., Gri, M., Ki.eTECKI, M. \& Afdukonic, $M$. (1997). Mecting the needs of children in resettlement process in Hvatska Kostajnica. International conference, 'Trauma recovery training: lessons learned', Zagreb, July 13-15, Abstracts No. 61

Dzerina, M., Prebe.G., Z., JuResa, V., Bogdan-Matjan, K., Brkljacic, D., ERdelJ-STIVICIC, B., LONCARDusek, M., Matijasevic, M., Rogosic-Timer, C., Smud, B., Sturz, B., Sarac, S. \& Tomorad, N. (1992). Suffering of Croatian school children during war. Croatian Medical fournal 33 (War Suppl. 2), 4044.

Garbarino, J., Kostelny, K. \& Dubrow, N. (1991). No place to be a child: growing up in a war zone. Lexington, MA: Lexington Books.

Grguric, J. \& Hirsl-Hecej, V. (Eds) (1993). Program for providing minimum nutritional and health care requirements for children in Croatia. Zagreb: Committee for Coordination of Relief and Health Care for Children in Exceptional Circumstances.

Grguric, J. \& RemetA, D. (Eds) (1994). Report on the violation of the Convention on the Rights of the Children during the war in the Republic of Croatia. Zagreb: Governmental Office for Victims of War, Children's Rights Commission.

Horowitz, M., WILNER, N. \& Alvarez, W. (1979). Impact of event scale: a measure of subjective stress. Psychosomatic Medicine, 41, 209-218.

IVANEK, A. \& JAKOPOVIC, S. (1995). We have survivedhow to go on? (p. 170). Zagreb: Ministry of Education and Sports.

Kovacs, M. (1981). Rating scale to assess depression in school-aged children. Acta Paedopsychiatrica, 46, 305315.

Kuterovac, G., Dyregrov, A. \& Sturland, R. (1994). Children in war: a silent majority under stress. British Journal of Medical Psychology, 67, 363-375.

LOPIZIC, J. (1995). Neka iskustva u radu s djecom povratnicima na dubrovackom podrucju (Some experiences with repatriated children in Dubrovnik region). Paper presented at the 3rd Annual Conference of Croatian Psychologists, Bizovac, May 25-27.

MCCALIIN, M. \& FozzARD, S. (Eds) (1990). The impact of traumatic events on the psychological well-being of Mozambican refugee women and children. Geneva: International Catholic Child Bureau.

MILGRAM, N.A. (1982). War related stress in Israeli children and youth. In: L. GolDBERG, \& S. BRENITZ (Eds), Handbook of stress: theoretical and clinical aspects (pp. 656-676). New York: The Free Press.

Milgram, R.M. \& Milgram, N.A. (1976). The effects of the Yom Kippur war on anxiety level in Israeli children. fournal of Psychology, 34, 107-1 13.

Moro, Lj. \& VIDOVIC, V. (1992). Psihicke promjene u djece i odraslih prognanika (Psychological changes in displaced children and adults). In: E. KLAIN (Ed.), Ratna psihologija i psihijatrija (War psychology and psychiatry) (pp. 162-171). Zagreb: Ratni stozer Republike Hrvatske.

ODPR (Governmental Office for Displaced People and Refugees) (1992). Newsletter, 11, 1-4

ODPR (1997). Izvjesce o prereregistraciji prognanika, povratnika $i$ izbjeglica u Republici Hrvatskoj (Report 
elin-

eb:

in's

[mess. iluill preregistration of displaced people, returnees and Irlukces in the Republic of Croatia). June, 1-4.

"Wll lick WaR VICTIMS (1995). Stradalnici domovinskog wmu (Victims of patriotic war) (pp. 1-6), Zagreb: The (iirvernment of the Republic of Croatia.

HuINIIR, R.P. (1984). Handbook for the study of parental uteplance and rejection. Hartford: University of Conlleclicut: Center for the study of Parental Acceptance IInI Rejection.

Hk\|, N., Zuzul, M. \& FATTORINI. I. (Eds) (1994). Vircslanje djece $u$ domovinskom ratu (Child suffering in We putriotic war), Zagreb: Slap and Children's Clinic.

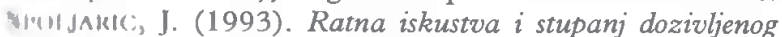
ureses djece iz podrucja razlicito zahvacenih ratom (WarIsluted experience and the level of distress among chil- dren). Master thesis. Zagreb: Department of Psychology, University of Zagreb.

SvoB, M. (Ed.) (1993). Prognana i izbjegla djeca u Zagrebu (Displaced and refugee children in Zagreb). Zagreb: Institute for Migration and Nationalities, University of Zagreb.

VRDOLJAK, LJ. (1995). Izrazenost deperesivnih simptoma kod prognane djece osnovnoskolskog uzrasta (Level of depression among refugee children in elementary school). Paper presented at the 3rd Annual Conference of Croatian Psychologists, Bizovac, May 25-27.

ZIVCIC, I. (1993). Emotional reactions of children to war stress in Croatia. Fournal of The American Academy of Child and Adolescent Psychiatry, 32, 709-713. 